\title{
PERMINTAAN PARIWISATA INDONESIA: STUDI KASUS WISATAWAN MALAYSIA
}

\author{
Devanto Shasta Pratomo \\ Fakultas Ekonomi Universitas Brawijaya
}

\begin{abstract}
This research attempts to study the effect of income per capita in Malaysia (GDP), relative prices (CPI) and Visit Indonesia Year 1991 to Indonesia tourism demand among Malaysian visitors. Malaysian visitors' arrivals to Indonesia are used as a proxy of Indonesia tourism demand among Malaysian visitors. In other words, an increase in the Malaysian visitor arrivals to Indonesia indicates an increase in the tourism demand among Malaysian visitors, vice versa. The data used in this study are quarterly secondary data for the period 1989.1-1997.4 consisting of total Malaysian visitor arrival to Indonesia, income per capita in Malaysia, and ratio of consumer price index of Indonesia to consumer price index of Malaysia. The analysis method applied in this study is regression using Error Correction Model (ECM). The results show that income per capita of Malaysia is elastic and positively affects Malaysian visitor arrivals to Indonesia. On the other hand, relative prices negatively affect Malaysian visitor arrivals to Indonesia, while Visit Indonesia Year 1991 positively affects Malaysian visitor arrivals to Indonesia.
\end{abstract}

Keywords: tourism, GDP, CPI, and ECM

\section{A. LATAR BELAKANG}

Dalam dua dekade terakhir, pertumbuhan pariwisata melaju dengan pesat. Perjalanan dan kepariwisataan meliputi angkutan, perhotelan, restoran, rekreasi dan jasa-jasa perjalanan wisata telah menjadi industri terbesar dunia dan pencipta lapangan kerja yang cukup besar. Industri ini diseluruh dunia diperkirakan menyumbang sebesar US\$ 3,8 triliun kepada produk bruto dunia dengan 262 juta lapangan kerja dalam tahun 1997, dan tumbuh menjadi US\$ 7,1 triliun dengan 383 juta lapangan kerja dalam tahun 2007. Studi dari World Travel and Tourism Council ini mengatakan bahwa pariwisata tumbuh hampir dua kali lipat lebih cepat dari produk bruto dunia (Jusuf, 1997: 5)

Pertumbuhan pariwisata dunia sangat dipengaruhi oleh dua faktor. Pertama faktor luar, yaitu faktor yang tidak berkaitan langsung dengan industri pariwisata tetapi mempengaruhi bentuk permintaan pariwisata. Contohnya Krisis Teluk yang bersifat lokal tetapi mampu mengganggu stabilitas politik global dan melibatkan banyak negara dan menjadi isu internasional. Secara tidak langsung, tidak adanya stabilitas politik global membuat angka permintaan pariwisata turun secara drastis karena wisatawan merasa tidak aman untuk melakukan perjalanan. Faktor kedua adalah kekuatan pasar; yaitu permintaan, penawaran dan distribusi produk dan pelayanan wisata. Dari kedua kategori umum diatas dapat disimpulkan bahwa faktor-faktor pokok yang selalu mempunyai pengaruh besar terhadap aktivitas pariwisata global adalah kondisi perekonomian dan politik global, serta perkembangan yang mempengaruhi tingkat keselamatan perjalanan wisata. Faktor-faktor inilah yang merupakan faktor mendasar bagi pertumbuhan pariwisata (Parikesit dan Trisnadi, 1997:4).

Dilihat dari segi kawasan, maka kawasan Asia Pasifik adalah kawasan yang tumbuh paling 
cepat diukur dari jumlah kunjungan wisatawan mancanegara, kegiatan ekonomi, investasi dan lapangan pekerjaan. Dalam kawasan ini Asia Tenggara diperkirakan akan menunjukkan laju pertumbuhan tercepat. Indonesia karena itu berada dalam posisi menguntungkan di pusat pertumbuhan dan perkembangan perjalanan dari pariwisata dunia.

Tabel 1. Kunjungan Wisatawan Mancanegara dari 5 Negara dengan Pangsa Pasar Terbesar ke Indonesia (\%)

\begin{tabular}{c|c|c|c|c|cc}
\hline \multicolumn{3}{c|}{ Urutan } & \multirow{2}{*}{ Nega ra A sa l } & \multicolumn{3}{|c}{ K un jungan (\%) } \\
\cline { 1 - 1 } $\mathbf{1 9 9 0}$ & $\mathbf{1 9 9 5}$ & $\mathbf{2 0 0 0}$ & & $\mathbf{1 9 9 0}$ & $\mathbf{1 9 9 5}$ & $\mathbf{2 0 0 0}$ \\
\hline 1 & 1 & 1 & S ingapura & 26,8 & 22,3 & 34,7 \\
3 & 3 & 2 & M a lay sia & 8,8 & 11,2 & 10,2 \\
5 & 4 & 3 & T aiwa n & 5,7 & 8,2 & 9,2 \\
2 & 2 & 4 & J ep ang & 12,3 & 11,6 & 8,7 \\
4 & 5 & 5 & A u stralia & 7,8 & 7,6 & 7,9 \\
\hline
\end{tabular}

Sumber: Travel and Tourism Intelligence, Asia Pacific Tourism Forecasts, 2000-2004, (2000)

Dilihat dari pasar wisatawan di Indonesia, negara-negara ASEAN selama ini merupakan pasar yang sangat potensial di Indonesia. Dalam hal ini, Malaysia adalah penyumbang wisatawan terbesar kedua dari kawasan ASEAN bagi Indonesia setelah Singapura. Dibandingkan wisatawan Singapura yang didominasi oleh tujuan bisnis, maka lebih dari 50\% dari wisatawan Malaysia memiliki motivasi untuk berlibur. Secara signifikan pula pengeluaran wisatawan per kunjungan wisatawan Malaysia lebih besar dan lama tinggal rata-rata wisatawan Malaysia akan lebih lama dibandingkan wisatawan Singapura.

Kedekatan historis dan geografis, kemudahan masuk, kekuatan mata uang dan biaya perjalanan yang rendah juga telah mendorong Malaysia sebagai sumber wisatawan yang signifikan secara konstan dalam lima tahun terakhir. Dengan pendapatan per kapita yang terus meningkat diharapkan Malaysia dapat terus menjadi salah satu pangsa pasar utama pariwisata Indonesia. Meskipun demikian kebanyakan wisatawan Malaysia ini hanya mempergunakannya untuk sekedar berakhir minggu atau perjalanan pendek (short haul) untuk berlibur atau bisnis. Oleh karena itu untuk mendayagunakan pasar potensial ini, berbagai strategi ekspansif untuk menarik wisatawan Malaysia pada khususnya dan wisatawan ASEAN pada umumnya ini perlu dirumuskan terutama agar lebih lama tinggal dan penyebaran tempat tujuan wisata yang lebih merata. Selama ini sebagian besar wisatawan Malaysia lebih memilih Batam, Sumatera, dan Jakarta sebagai daerah tujuan wisata mereka.

Tabel 2. Perkembangan Indikator Permintaan Pariwisata Indonesia oleh Wisatawan Malaysia, 1990-1998

\begin{tabular}{lc|cc}
\hline $\mathbf{1 9 9 0}$ & 189.446 & $\begin{array}{c}\text { Rata-Rata Pengeluaran } \\
\text { Per Kunjungan (US \$) }\end{array}$ & $\begin{array}{c}\text { Rata-Rata Lama Tinggal Per } \\
\text { Wisata wan (hari) }\end{array}$ \\
\hline $\mathbf{1 9 9 1}$ & 316.475 & 548,83 & 6,08 \\
$\mathbf{1 9 9 2}$ & 338.049 & 493,01 & 5,23 \\
$\mathbf{1 9 9 3}$ & 361.089 & 629,38 & 6,07 \\
\hline $\mathbf{1 9 9 4}$ & 371.457 & 787,38 & 8,42 \\
\hline $\mathbf{1 9 9 5}$ & 511.903 & 712,45 & 6,14 \\
$\mathbf{1 9 9 6}$ & 392.562 & 742,52 & 6,12 \\
$\mathbf{1 9 9 7}$ & 481.713 & 870 & 7,89 \\
\hline $\mathbf{1 9 9 8}$ & 491.597 & 828,04 & 6,59 \\
\hline
\end{tabular}

Sumber: Deparsenibud, Analisis Pasar Wisatawan Mancanegara, 1999 


\section{Journal of Indonesian Applied Economics}

Vol. 3 No. 2 Oktober 2009, 200-209

Pertumbuhan wisatawan Malaysia yang terus berkembang setiap tahunnya dengan tingkat pertumbuhan sebesar kurang lebih $10 \%$ per tahun merupakan sebuah peluang yang harus dimanfaatkan secara optimal. Kondisi tersebut didorong oleh pertumbuhan ekonomi Malaysia secara makro yang terus mengalami penguatan baik di sektor riil maupun sektor moneter sehingga mendorong kemampuan ekonomi penduduk Malaysia dan kemampuan untuk berwisata ke luar negeri. Malaysia telah dapat memulihkan kondisi negaranya dari keterpurukan akibat krisis ekonomi, sehingga roda perekonomian Malaysia dapat terus berjalan dan memacu pertumbuhan ekonominya secara signifikan. Di lain pihak, Indonesia yang lambat di dalam penanganan krisis yang berdampak pada lemahnya nilai tukar Rupiah terhadap US Dollar juga telah memungkinkan Indonesia sebagai negara tujuan wisata yang murah (Deparsenibud, 1999:12).

Berdasar hal diatas maka penelitian untuk mengidentifikasi faktor-faktor yang mempengaruhi permintaan pariwisata di Indonesia, dengan studi kasus wisatawan Malaysia adalah penting dan menarik untuk dikaji. Analisis permintaan ini dapat digunakan untuk tujuan manajemen industri pariwisata Indonesia dan untuk tujuan perencanaan bagi pembuat kebijakan dalam industri pariwisata terhadap negara asal wisatawan.

\section{B. KAJIAN TEORITIS}

\section{Definisi-definisi Kepariwisataan}

Menurut definisi yang luas pariwisata adalah perjalanan dari satu tempat ke tempat lain, bersifat sementara, dilakukan perorangan atau kelompok, sebagai usaha untuk mencari keseimbangan atau keserasian dan kebahagiaan dengan lingkungan hidup dalam dimensi sosial, budaya, alam, dan ilmu (Spillane, 1987:21). Menurut Lindberg dkk (1997:6) sebagai suatu konsep, pariwisata dapat ditinjau dari berbagai segi berbeda. Pariwisata dapat dilihat sebagai suatu kegiatan melakukan perjalanan dari rumah dengan maksud tidak melakukan usaha atau bersantai. Pariwisata dapat juga dilihat sebagai suatu bisnis, yang berhubungan dengan penyediaan barang dan jasa bagi wisatawan dan menyangkut setiap pengeluaran oleh atau wisatawan dalam perjalanannya.

World Tourism Organization (WTO) dan International Union of Office Travel Organization (IUOTO) mendefinisikan wisatawan sebagai setiap pengunjung yang tinggal paling sedikit 24 jam, akan tetapi tidak lebih dari 6 (enam) bulan di tempat yang dikunjunginya dengan maksud kunjungan antara lain: (1) berlibur, rekreasi, dan olahraga, (2) bisnis, mengunjungi teman dan keluarga, misi, menghadiri pertemuan, konferensi, kunjungan dengan alasan kesehatan, belajar, atau kegiatan keagamaan. Adapun Badan Pusat Statistik mendefinisikan pelancong sebagai setiap pengunjung yang tingal kurang dari 24 jam di tempat yang dikunjunginya.

\section{Teori Permintaan}

Konsep permintaan digunakan untuk menunjukkan keinginan-keinginan seorang pembeli pada suatu pasar. Sementara itu fungsi permintaan menunjukkan hubungan antara kuantitas suatu barang yang diminta dengan semua faktor yang memperngaruhinya (Arsyad, 1997: 25). Permintaan seseorang atau sesuatu masyarakat keatas suatu barang ditentukan oleh banyak faktor. Di antara faktor-faktor tersebut yang secara umum mempengaruhi permintaan suatu barang adalah harga barang itu sendiri, harga barang-barang lain yang mempunyai kaitan erat dengan barang tersebut, pendapatan konsumen yang tersedia untuk dibelanjakan, dan selera konsumen dan faktor lain yang besarnya sulit diukur secara langsung.

Dalam menjelaskan perubahan jumlah barang yang diminta dapat diterangkan dengan menganalisis dua faktor, yaitu efek substitusi (substitution effect) dan efek pendapatan (income effect). Efek substitusi adalah perubahan jumlah suatu barang yang diminta jika ada perubahan harga, sementara pendapatan disesuaikan agar tingkat kepuasan konsumen tetap seperti semula. Penurunan harga akan menambah permintaan karena konsumen akan lebih banyak mengkonsumsi barang itu dan mengurangi konsumsi barang lain, demikian pula sebaliknya. Efek pendapatan adalah perubahan jumlah suatu barang yang diminta jika terjadi perubahan pendapatan riil, dengan 
anggapan harga tidak mengalami perubahan. Penurunan harga akan menambah pendapatan riil konsumen dan kenaikan pendapatan riil ini akan menambah konsumsi berbagai barang demikian pula sebaliknya.

Konsep lain dalam teori permintaan yang juga berguna untuk mengetahui sampai dimana responsifnya permintaan terhadap perubahan harga adalah elastisitas permintaan. Elastisitas permintaan dibedakan pada tiga konsep, yaitu elastisitas harga permintaan, elastisitas silang, dan elastisitas pendapatan. Elastisitas harga permintaan mengukur derajat kuantitas barang yang dibeli sebagai akibat perubahan harga barang tersebut. Disisi lain, elastisitas silang mengukur derajat kuantitas barang yang dibeli sebagai akibat perubahan harga barang lain. Sedangkan elastisitas pendapatan mengukur derajat kuantitas barang yang dibeli sebagai akibat perubahan pendapatan pembeli.

\section{Variabel-variabel Penentu Permintaan Pariwisata}

Dalam analisis tentang permintaan pariwisata ke suatu negara ada beberapa variabel yang selalu digunakan para peneliti dalam membuat sebuah spesifikasi model ekonometrika. Variabel-variabel tersebut diantaranya adalah pendapatan, harga, populasi, trend dan variabel boneka (Witt dan Witt, 1992: 16-26). Pendapatan adalah salah satu faktor terpenting sebagai penentu permintaan pariwisata ke suatu tempat. Tingginya pendapatan menggambarkan bahwa wisatawan telah memiliki standar hidup yang tinggi sehingga memungkinkan untuk melakukan perjalanan antar negara. Hal ini dikarenakan berwisata antar negara dalam sebagian besar kasus masih dikategorikan sebagai barang mewah (lux). Disamping itu dengan naiknya pendapatan akan menimbulkan kecenderungan terhadap pengurangan jam kerja yang memungkinkan panjangnya masa liburan dan meningkatnya uang yang dibelanjakan.

Harga adalah variabel penting lain sebagai penentu permintaan pariwisata. Setiap terjadinya penurunan harga maka wisatawan akan membayar biaya wisata dengan lebih murah. Implikasi lainnya adalah wisatawan dapat memperpanjang lama tinggal dan menambah tempat kunjungannya. Dalam pariwisata terdapat dua elemen harga yang biasa digunakan, yaitu biaya perjalanan dan biaya tinggal wisatawan di tempat tujuan (Witt dan Witt, 1992: 18). Biaya tinggal wisatawan biasa diukur dengan kurs atau indeks harga konsumen relatif.

Besarnya populasi suatu negara asal wisatawan diharapkan juga akan meningkatkan permintaan pariwisata ke suatu negara. Namun variabel ini sering oleh peneliti tidak dimasukkan sebagai suatu variabel yang terpisah dalam estimasi ekonometrika karena kemungkinan terjadinya multikolinearitas terutama terhadap variabel lain yang memakai unsur per kapita (Shuib dan Noor, 1989: 430).

Variabel trend sering dimasukkan dalam model permintaan pariwisata untuk menggambarkan perubahan selera wisatawan terhadap suatu daerah tujuan. Selain itu beberapa peneliti juga memasukkan variabel trend untuk melihat perubahan frekuensi penerbangan dan perubahan demografi pada negara asal (Witt dan Witt, 1992: 24). Selanjutnya variabel boneka digunakan peneliti untuk menggambarkan dampak suatu kejadian terhadap permintaan pariwisata suatu negara. Variabel boneka yang sering digunakan adalah resesi ekonomidan tahun-tahun promosi suatu negara. Menurut Mill (1985: 52-56), variabel-variabel sosial ekonomi juga terbukti erat kaitannya dengan permintaan untuk pariwisata. Adapun variabel-variabel seperti umur, jenis kelamin, tingkat pendidikan, jenis pekerjaan merupakan penentu permintaan pariwisata yang signifikan.

Dua pendekatan utama yang biasa digunakan peneliti terdahulu dalam menyusun model permintaan pariwisata yaitu pendekatan sistem permintaan (system of demand models) dan pendekatan persamaan tunggal (single equation models). Pendekatan pertama, pendekatan sistem permintaan digunakan untuk menjelaskan alokasi pengeluaran pariwisata untuk antar negara dan mengestimasi sensitivitas anggaran suatu negara untuk berubah dalam harga relatif dan pengeluaran (Singh dan Siregar, 1997). Berdasar tujuan penelitian yang ada, pendekatan pertama ini tidak digunakan dalam penelitian ini.

Selanjutnya, pendekatan persamaan tunggal dapat diukur dengan pengeluaran wisatawan, jumlah kunjungan wisatawan dan lama wisatawan tinggal. Secara umum diterima bahwa kunjungan 
wisatawan dapat tergantung pada pendapatan, harga relatif atau nilai tukar, biaya transportasi antar negara asal dan tujuan, pengeluaran pemasaran atau promosi dan shock dalam pariwisata seperti kondisi politik atau acara-acara olahraga dunia (Hitchcock, 1993:204-205).

Hubungan antara permintaan pariwisata dan variabel-variabel yang mempengaruhinya bisa diestimasi dengan menggunakan analisis regresi berganda. Studi runtun waktu dalam analisis regresi berganda tentang permintaan pariwisata ini telah banyak dilakukan oleh peneliti terdahulu, seperti yang dilakukan oleh Shuib dan Noor (1989), Hamal (1997), serta Vanegas dan Croes (2000).

Selain itu dengan menggunakan fungsi log-linear dapat ditemukan tingkat elastisitas yang menunjukkan sensitivitas jangka pendek dan jangka panjang. Penelitian tentang elastisitas permintaan pariwisata di beberapa negara maju yang dilakukan oleh Hall dan Page (1999), menemukan bahwa permintaan pariwisata adalah sangat peka terhadap bertambahnya pendapatan disposibel dari negara asal wisatawan, sedangkan kemampuan kunjungan untuk berubah dalam harga dan nilai tukar adalah bervariasi antar negara.

\section{Penelitian Terdahulu}

Adapun penelitian terdahulu yang menjadi acuan utama dalam penelitian ini adalah penelitian dari Vanegas dan Croes (2000). Mereka meneliti tentang permintaan pariwisata Aruba oleh wisatawan Amerika Serikat. Dengan alat analisis regresi berganda model penyesuaian parsial (Partial Adjustment Model) penelitian Vanegas dan Croes (2000) menyimpulkan bahwa pendapatan per kapita Amerika Serikat memiliki efek yang lebih besar terhadap permintaan pariwisata Aruba dibandingkan dengan variabel nilai tukar dan harga. Ditinjau dari tingkat elastisitasnya wisatawan Amerika Serikat sangat sensitif dengan perubahan pendapatan dan inelastis terhadap perubahan harga.

Walaupun demikian, terdapat sedikit perbedaan dari model yang digunakan oleh Vanegas dan Croes (2000) dengan penelitian ini. Untuk variabel independen yang dipakai, ada beberapa variabel yang telah dimodifikasi, yaitu penggunaan variabel boneka tahun kunjungan wisata Indonesia (Visit Indonesia Year 1991) yang menggambarkan dampak promosi pariwisata Indonesia paling penting pada era 90 -an. Selanjutnya dalam penelitian ini tidak memperhitungkan lagi pengaruh nilai tukar riil terhadap jumlah kunjungan wisatawan. Hal ini dikarenakan kemungkinan terjadinya multikolinearitas antara nilai tukar riil dan harga relatif, seperti yang dikemukakan oleh Vanegas dan Croes (2000).

\section{Hipotesis}

Adapun hipotesis dalam penelitian ini dapat dirumuskan sebagai berikut.

1. Diduga pendapatan per kapita Malaysia adalah elastis dan berpengaruh positif terhadap permintaan pariwisata Indonesia oleh wisatawan Malaysia.

2. Diduga harga relatif adalah berpengaruh negatif terhadap permintaan pariwisata Indonesia oleh wisatawan Malaysia.

3. Diduga tahun kunjungan wisata Indonesia (Visit Indonesia Year 1991) berpengaruh psoitif terhadap permintaan pariwisata Indonesia oleh wisatawan Malaysia.

\section{METODE PENELITIAN DAN ANALISIS DATA}

Jumlah kunjungan wisatawan dalam penelitian ini merupakan proksi dari permintaan pariwisata, seperti disarankan oleh Hamal (1997) dan Vanegas dan Croes (2000). Fungsi permintaan pariwisata Indonesia dengan studi kasus wisatawan Malaysia dalam penelitian ini dapat dihubungkan seperti persamaan berikut.

$$
\mathrm{TA}=\mathrm{f}(\mathrm{GDP}, \mathrm{PRI}, \mathrm{D} 1)
$$

Dimana dalam persamaan ini:

TA = Jumlah Wisatawan Malaysia yang berkunjung ke Indonesia; 
GDP $=$ Pendapatan per kapita negara Malaysia berdasarkan harga konstan tahun 1990;

PRI = Harga relatif Indonesia terhadap Malaysia berdasarkan harga konstan tahun 1990;

D1 = Variabel boneka untuk Visit Indonesia Year 1991

Variabel dependen dalam persamaan diatas menunjukkan jumlah wisatawan Malaysia yang berkunjung ke Indonesia. Dengan kata lain, setiap penambahan jumlah wisatawan Malaysia yang berkunjung ke Indonesia mengindikasikan bertambahnya permintaan pariwisata Indonesia oleh wisatawan Malaysia, demikian pula sebaliknya. Pendapatan per kapita dan harga relatif diasumsikan sebagai variabel yang signifikan dalam fungsi permintaan pariwisata. Harga relatif adalah proksi dari variabel biaya tinggal wisatawan Malaysia di Indonesia, sedangkan pendapatan per kapita digunakan sebagai proksi untuk pendapatan disposibel wisatawan. Variabel boneka dari VIY 1991 adalah promosi pemerintah Indonesia paling penting dalam era tahun 1990-an.

Dalam penelitian ini data yang digunakan adalah data sekunder runtun waktu kuartalan dari periode 1989.1 sampai 1997.4. Data jumlah kunjungan wisatawan didapat dari Statistik Kunjungan Tamu Asing terbitan BPS untuk periode 1992.1 sampai periode 1997.4 dan dari Statistical Report on Visitor Arrivals to Indonesia terbitan Departemen Pariwisata, Pos, dan Telekomunikasi untuk periode 1989.1 sampai periode 1991.4. Data pendapatan per kapita didapat dari International Financial Statistics, terbitan International Monetary Fund dalam periode tahunan. Untuk mengubah menjadi bentuk periode kuartalan digunakan teknik interpolasi linier yang dikembangkan oleh Insukindro (1995:42) sebagai berikut.

$$
\begin{aligned}
& \mathrm{Y}_{\mathrm{t}} 1=1 / 4\left\{\mathrm{Y}_{\mathrm{t}}-4,5 / 12\left(\mathrm{Y}_{\mathrm{t}}-\mathrm{Y}_{\mathrm{t}-1}\right)\right\} \\
& \mathrm{Y}_{\mathrm{t}} 2=1 / 4\left\{\mathrm{Y}_{\mathrm{t}}-1,5 / 12\left(\mathrm{Y}_{\mathrm{t}}-\mathrm{Y}_{\mathrm{t}-1}\right)\right\} \\
& \mathrm{Y}_{\mathrm{t}} 3=1 / 4\left\{\mathrm{Y}_{\mathrm{t}}-+1,5 / 12\left(\mathrm{Y}_{\mathrm{t}}-\mathrm{Y}_{\mathrm{t}-1}\right)\right\} \\
& \mathrm{Y}_{\mathrm{t}} 4=1 / 4\left\{\mathrm{Y}_{\mathrm{t}}+4,5 / 12\left(\mathrm{Y}_{\mathrm{t}}-\mathrm{Y}_{\mathrm{t}^{-}}\right)\right\} \\
& \text {Keterangan: } Y_{t}=\text { PDB per kapita periode/tahun } t \\
& \mathrm{Y}_{\mathrm{t}-1} \quad=\mathrm{PDB} \text { per kapita periode/tahun } \mathrm{t}-1 \\
& \mathrm{Y}_{\mathrm{t}} 1=\mathrm{PDB} \text { per kapita triwulan pertama tahun } \mathrm{t} \\
& \mathrm{Yt} 2=\mathrm{PDB} \text { per kapita triwulan kedua tahun } \mathrm{t} \\
& \text { Yt3 = PDB per kapita triwulan ketiga tahun } \mathrm{t} \\
& \mathrm{Yt} 4=\text { PDB per kapita triwulan keempat tahun } \mathrm{t}
\end{aligned}
$$

Selanjutnya data harga relatif, yang merupakan rasio dari indeks harga konsumen Indonesia terhadap indeks harga konsumen Malaysia, diolah dari data International Financial Statistics. Periode waktu sudah tersedia dalam bentuk kuartalan.

Alat analisis yang digunakan dalam penelitian ini adalah analisis OLS dengan pendekatan model koreksi kesalahan (Error Correction Model $=E C M$ ). Model ECM ini memiliki berbagai keunggulan dibandingkan misalnya dengan model penyesuaian parsial (PAM). Pendekatan ini diyakini dapat menguji apakah spesifikasi model empirik yang digunakan valid atau tidak berdasarkan nilai koefisien Error Correction Term (ECT). Dengan pendekatan ini juga dapat meliput lebih banyak variabel dalam menganalisis fenomena ekonomi jangka pendek dan jangka panjang serta mengkaji konsisten tidaknya model empirik dengan teori ekonomi, dan dalam usaha mencari pemecahan terhadap persoalan variabel runtun waktu yang tidak stasioner dan regresi lancung dalam analisis ekonometrika (Insukindro dan Aliman, 1999: 54-55).

Dengan demikian model ECM permintaan pariwisata Indonesia oleh wisatawan Malaysia yang digunakan dalam penelitian ini adalah sebagai berikut:

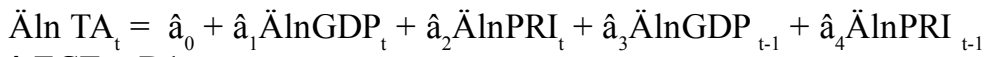

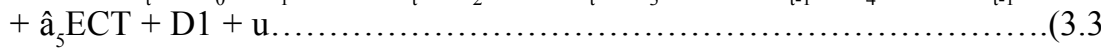

Fungsi log-linear dalam analisis ini digunakan untuk mengestimasi model permintaan pariwisata Indonesia. Dengan menggunakan fungsi log-linear dapat menunjukkan elastisitas dari variabel dependen yang dalam hubungannya dengan variabel independen adalah konstan. 


\section{Journal of Indonesian Applied Economics}

Vol. 3 No. 2 Oktober 2009, 200-209

\section{HASIL DAN PEMBAHASAN}

Hasil estimasi model koreksi kesalahan (ECM) dengan OLS terhadap permintaan pariwisata Indonesia oleh wisatawan Malaysia berdasarkan persamaan 3.3 dapat dilihat pada tabel 3 berikut. Dari tabel 3 juga dapat diketahui bahwa model ECM yang digunakan selama periode penelitian telah berhasil dalam mengestimasi terhadap model permintaan pariwisata Indonesia, dengan studi kasus wisatawan Malaysia. Indikasi awal dari keberhasilan penggunaan model ECM ini dapat dilihat dari signifikannya secara statistik nilai koefisien ECT yang sekaligus menunjukkan benarnya spesifikasi model yang digunakan. Nilai koefisien ECT dalam model ECM ini signifikan secara statistik pada derajat kepercayaan 5\% dan bernilai positif kurang dari satu.

Uji secara parsial (t-statistik) dilakukan dengan maksud melihat pengaruh variabel bebas secara satu per satu terhadap variabel tak bebas. Metode lain yang biasa digunakan adalah dengan melihat nilai probabilitas ( $\mathrm{p}$-value) dari masing-masing variabel. Berdasarkan nilai p-value ternyata secara individu variasi jumlah wisatawan Malaysia yang berkunjung ke Indonesia dipengaruhi oleh pendapatan per kapita dalam jangka panjang dan harga relatif dalam jangka pendek dan jangka panjang pada derajat signifikansi 5\%. Hal ini terlihat dari nilai p-value yang lebih kecil dari 0,05 .

Koefisien determinasi $\left(\mathrm{R}^{2}\right)$ dalam analisis regresi linier yang diestimasi dengan OLS menjelaskan proporsi variabel-variabel tak bebas yang mampu dijelaskan oleh variasi variabel bebasnya. Dengan demikian dari tabel 3 juga dapat diketahui bahwa persamaan regresi linier tersebut mempunyai nilai koefien determinasi sebesar 0,468, yang berarti bahwa 46,8\% dari variasi variabel jumlah wisatawan Malaysia yang berkunjung ke Indonesia selama periode penelitian mampu dijelaskan oleh variasi himpunan variabel bebasnya. Rendahnya nilai koefisien determinasi tidak menjadi kendala karena dalam model ECM sendiri yang diestimasi adalah variabel dalam bentuk firstdifference, sehingga dapat dpastikan bahwa nilai koefisien determinasinya adalah jauh lebih rendah dibandingkan dengan estimasi model dalam bentuk level (Aliman, 2000:95).

Uji F dilakukan untuk menjelaskan pengaruh variabel-variabel bebas secara serentak terhadap variabel tak bebas. Uji F dalam hal estimasi model ini menunjukkan angka sebesar 4,25 dan secara statistik signifikan pada derajat keyakinan alpha $=5 \%$. Hal ini berarti secara bersama-sama variabel bebas (DLGDP, DPRI, LGDP(-1), PRI(-1), D1) mempengaruhi variabel terikat.

Dari hasil uji diagnostik terhadap estimasi model ECM ini juga menunjukkan bahwa model ini lolos dari semua uji penyimpangan asumsi klasik regresi linier. Pengujian terhadap normalitas ditujukan untuk melihat apakah faktor pengganggu memiliki distribusi normal. Uji normalitas ini dilakukan dengan menggunakan uji Jarque-Bera. Hasil uji menunjukkan bahwa J-B hitung sebesar 1,81 dan jauh lebih kecil dari $\mathrm{X}^{2}$ tabel dengan degree of freedom $(\mathrm{df}=2)$ sebesar 5,99. Dengan demikian dapat disimpulkan bahwa model estimasi ECM yang digunakan adalah mempunyai faktor pengganggu yang berdistribusi normal.

Pengujian terhadap linieritas bertujuan untuk melihat apakah spesifikasi model yang digunakan sudah benar atau tidak. Dengan uji linieritas akan diperoleh informasi tentang bentuk model empiris yan benar dan variabel yang relevan untuk dimasukkan ke dalam model empiris. Pengujian linieritas terhadap model estimasi ECM ini menggunakan uji yang dikembangkan Ramsey (Ramsey RESET Test). Dengan menggunakan uji Ramsey ditemukan besarnya nilai F hitung adalah 1,57 . Dengan demikian berdasarkan hasil uji Ramsey dapat disimpulkan bahwa model estimasi ECM ini adalah benar spesifikasinya dalam bentuk linier. Hal ini ditunjukkan dengan nilai $\mathrm{F}$ hitung yang lebih kecil dibandingkan dengan nilai $\mathrm{F}$ tabel $(8,36)$ sebesar 1,94 .

Pengujian terhadap ada tidaknya autokorelasi dilakukan dengan menggunakan uji Dirbin Watson (DW test). Berdasarkan hasil estimasi model empiris yang digunakan ditemukan besarnya nilai DW hitung (d) sebesar 2,06. Dengan jumlah observasi sebesar 36 dan jumlah variabel bebas sebanyak $\mathrm{k}=6$, maka diketahui besarnya nilai $\mathrm{D}-\mathrm{W}$ tabel pada tingkat kepercayaan alpha $=5 \%(\mathrm{dl}=1,11 ; \mathrm{du}=1,88$; 4-du=2,12; 4-dl=2,89). Dengan demikian berdasarkan uji D-W, model estimasi ECM ini tidak terkena masalah autokorelasi karena $\mathrm{du}<\mathrm{d}<\mathrm{dl}$. 
Uji ada tidaknya heteroskedastisitas dalam model estimasi ECM ini menggunakan uji ARCH (Autoregressive Conditional Heteroscedasticity). Dari hasil uji ARCH ditemukan besarnya nilai $\mathrm{X}^{2}$ hitung sebesar 0,00038 , sementara $\mathrm{X}^{2}$ tabel (1) dengan alpha $=5 \%$ sebesar 3,84. Hal ini menujukkan bahwa berdasarkan pada uji ARCH maka model empiris yang digunakan tidak ditemukan adanya heteroskedastisitas karena nilai $\mathrm{X}^{2}$ hitung yang lebih kecil daripada $\mathrm{X}^{2}$ tabel.

Dari hasil estimasi model ECM ini dapat dipisahkan menjadi analisis jangka pendek dan jangka panjang. Dari hasil estimasi dalam jangka pendek menunjukkan bahwa pendapatan per kapita tidak menunjukkan signifikansi pada derajat keyakinan 5\%. Tidak signifikannya pendapatan per kapita dalam jangka pendek ini mengindikasikan bahwa pengaruh pendapatan per kapita terhadap jumlah wisatawan Malaysia yang berkunjung ke Indonesia ini tidak dapat berlangsung seketika, sedangkan variabel hara relatif dalam jangka pendek berpengaruh terhadap jumlah wisatawan Malaysia yang berkunjung ke Indonesia. Hal ini ditunjukkan dengan signifikannya p-value dengan tingkat kepercayaan 5\%. Selanjutnya karena ECT mempunyai tanda positif dan secara statistik signifikan maka dapat dihitung koefisien jangka panjangnya sebagai berikut.

$$
\begin{aligned}
& \text { LGDP }=\left(\alpha_{3}+\alpha_{5}\right) / \alpha_{5}=(3,8299+0,4969) / 0,4969=8,7082 \\
& \text { PRI }=\left(\alpha_{4}+\alpha_{5}\right) / \alpha_{5}=(-3,8375+0,4969) / 0,4969=-6,7234
\end{aligned}
$$

Dalam jangka pendek pendapatan per kapita tidak menunjukkan signifikansi pada derajat keyakinan 5\%, namun dalam jangka panjang pendapatan per kapita signifikan dengan koefisien variabel nya sebesar 8,71 . Selanjutnya dalam jangka panjang mengandung pengertian bahwa adanya kenaikan pendapatan per kapita sebesar $1 \%$ akan menyebabkan kenaikan terhadap jumlah rata-rata wisatawan Malaysia yang berkunjung ke Indonesia sebesar $8,71 \%$, ceteris paribus. Besarnya angka elastisitas pendapatan per kapita yang lebih besar dari satu mengindikasikan bahwa pendapatan per kapita adalah bersifat elastis dan melakukan wisata ke Indonesia dikategorikan sebagai barang mewah (lux) bagi wisatawan Malaysia. Hal ini tentunya sesuai dengan berbagai penelitian terdahulu yang menyatakan bahwa pendapatan bersifat elastis atau sangat sensitif terhadap permintaan pariwisata. Kunjungan atau berwisata ke luar negeri juga masih dikateorikan sebagai barang mewah bagi kebanyakan negara termasuk didalamnya wisatawan Malaysia yang berkunjung ke Indonesia.

Nilai koefisien harga relatif dalam jangka pendek sebesar -3,22. Dari hasil estimasi ini dapat dijelaskan bahwa setiap adanya kenaikan harga relatif sebesar $1 \%$ maka jumlah rata-rata wisatawan Malaysia yang berkunjung ke Indonesia mengalami penurunan sebesar 3,22\%, ceteris paribus. Demikian pula dalam jangka panjang menunjukkan bahwa setiap terjadi kenaikan harga relatif sebesar $1 \%$ maka jumlah rata-rata wisatawan Malaysia yang berkunjung ke Indonesia mengalami penurunan sebesar $6,72 \%$, ceteris paribus. Besarnya koefisien harga relatif baik dalam jangka pendek maupun jangka panjang yang lebih besar dari satu ini juga mengindikasikan bahwa harga relatif sangat responsif terhadap perubahan harga relatif itu sendiri. Murahnya biaya tinggal di Indonesia tampaknya menjadi pertimbangan penting bagi wisatawan Malaysia dalam memutuskan melakukan kunjungannya ke Indonesia. Lemahnya nilai tukar Rupiah terhadap US Dollar juga telah memungkinkan Indonesia sebagai daerah tujuan wisata yang murah bagi wisatawan Malaysia.

Selanjutnya, variabel boneka tahun kunjungan wisata (Visit Indonesia Year 1991) berpengaruh positif terhadap jumlah kunjungan wisatawan Malaysia ke Indonesia dan secara statistik signifikan dengan nilai koefisien sebesar 0,26. Seperti diketahui bahwa tahun kunjungan wisata Indonesia ini merupakan ajang promosi pemerintah dalam bidang pariwisata paling penting pada era tahun 1990an. Nilai koefisien sebesar 0,26 ini mengindikasikan bahwa dengan adanya tahun kunjungan wisata Indonesia maka jumlah rata-rata wisatawan Malaysia yang berkunjung ke Indonesia akan meningkat. Hal ini membuktikan bahwa tahun kunjungan wisata merupakan salah satu promosi yang efektif untuk meningkatkan jumlah kunjungan wisatawan ke Indonesia. 
Journal of Indonesian Applied Economics

Vol. 3 No. 2 Oktober 2009, 200-209

\section{E. KESIMPULAN DAN REKOMENDASI}

Berdasarkan hasil analisis dan pembahasan, dapat diambil beberapa kesimpulan sebagai berikut.

1. Dari hasil estimasi model koreksi kesalahan (ECM) terhadap wisatawan Malaysia yang berkunjung ke Indonesia menunjukkan bahwa pendapatan per kapita Malaysia bersifat elastis dan berpengaruh positif dalam jangka panjang terhadap wisatawan Malaysia yang berkunjung ke Indonesia. Hal ini berarti bahwa dalam jangka panjang adanya kenaikan pendapatan per kapita Malaysia mengakibatkan peningkatan pada jumlah rata-rata wisatawan Malaysia yang berkunjung ke Indonesia dan sebaliknya, ceteris paribus. Secara implisit, setiap meningkatnya jumlah rata-rata wisatawan Malaysia yang berkunjung ke Indonesia mengindikasikan meningkatnya permintaan pariwisata Indonesia oleh wisatawan Malaysia. Kunjungan wisata ke Indonesia sendiri dikategorikan sebagai barang mewah oleh wisatawan Malaysia.

2. Dari model ECM yang dipakai ini juga mengindikasikan bahwa harga relatif berpengaruh negatif baik dalam jangka pendek maupun jnagka panjang terhadap jumlah wisatawan Malaysia yang berkunjung ke Indonesia. Hal ini berarti bahwa adanya kenaikan harga relatif di Indonesia terhadap negara asal wisatawan (Malaysia) akan mengakibatkan penurunan jumlah rata-rata wisatawan Malaysia yang berkunjung ke Indonesia dan sebaliknya, ceteris paribus. Secara implisit, setiap menurunnya jumlah rata-rata wisatawan Malaysia yang berkunjung ke Indonesia mengindikasikan menurunnya permintaan pariwisata Indonesia oleh wisatawan Malaysia.

3. Tahun kunjungan wisata Indonesia (Visit Indonesia Year 1991) sebagai promosi pemerintah paling penting pada era 1990-an memiliki peranan positif terhadap jumlah wisatawan Malaysia yang ebrkunjung ke Indonesia. Hal ini mengindikasikan keberhasilan tahun kunjungan wisata 1991 sebagai salah satu ajang yang efektif untuk meningkatkan jumlah wisatawan asing yang berkunjung pada umumnya dan wisatawan Malaysia pada khususnya ke Indonesia. Secara implisit, setiap meningkatnya jumlah rata-rata wisatawan Malaysia yang berkunjung ke Indonesia mengindikasikan meningkatnya permintaan pariwisata Indonesia oleh wisatawan Malaysia.

Dalam hubungannya dengan penelitian ini dapat dikemukakan rekomendasi sebagai berikut.

1. Dalam melakukan proyeksi terhadap permintaan pariwisata, khususnya terhadap wisatawan Malaysia yang berkunjung ke Indonesia, pemerintah hendaknya memperhitungkan variabel pendapatan per kapita dan harga relatif karena variabel tersebut telah terbukti sangat berpengaruh terhadap permintaan pariwisata Indonesia oleh wisatawan Malaysia.

2. Dalam penelitian ini tahun kunjugan wisata Indonesia (VIY) telah terbukti sebagai alat promosi dan informasi yang signifikan penerapannya terhadap permintaan pariwisata. Untuk itu pemerintah hendaknya membuat sebuah perencanaan terhadap pelaksanaan tahun kunjungan wisata Indonesia di masa yang akan datang secara berkala. Selain itu juga perlu dilakukan promosi yang bertujuan lebih mengenalkan daerah-daerah yang ada di Indonesia dengan paket-paket wisata murah ke daerah, karena selama ini wisatawan Malaysia hanya berkunjung ke daerah-daerah tujuan tertentu saja, seperti Batam, Sumatera, dan Jakarta. Ajang promosi yang efektif akan meningkatkan jumlah kunjungan secara signifikan. Pembukaan dan penambahan jalur-jalur baru ke berbagai tujuan yang ada di Indonesia juga akan sangat membantu bagi penyebaran daerah-daerah tujuan wisata tersebut.

3. Agar diperoleh informasi yang lebih akurat tentang variabel-variabel yang memiliki peranan terhadap permintaan pariwisata Indonesia, sebaiknya penelitian dilanjutkan dengan memperhitungkan variabel lain yang diduga berpengaruh pada permintaan pariwisata Indonesia selain variabel pendapatan dan harga, seperti biaya transportasi, populasi atau perubahan selera. Meskipun demikian perlu dicatat bahwa setiap negara asal wisatawan memiliki karakteristik terhadap pemintaan pariwisata yang berbeda. 


\section{DAFTAR PUSTAKA}

Aliman (2000), Modul Ekonometrika Terapan, PAU Sudi Ekonomi, Universitas Gadjah Mada, Yogyakarta.

Arsyad, L (1997), Ekonomi Mikro: Ikhtisar Teori dan Soal Jawab, BPFE, Yogyakarta.

Deparsenibud (1999), Informasi Pasar Wisatawan Mancanegara, Direktorat Bina Pemasaran Pariwisata, Jakarta.

Hall, C.M dan Page, S.J. (1999), The Geography of Tourism and Recreation, Routledge, London.

Hamal, K (1997), "Modeling Domestic Holiday Tourism Demand in Australia", Asia Pacific Journal of Tourism Research, Vol 1 (2), 35-46

Hitchcock, M., King, V., dan Parnwell, M., (1993), The Economics of Tourism in Asia and the Pacific, Routledge, London and New York.

Insukindro (1995), Ekonomi Uang dan Bank, BPFE, Yogyakarta.

Insukindro dan Aliman (1999), "Pemilihan dan Bentuk Fungsi Model Empirik: Studi Kasus Permintaan Uang Kartal Riil di Indonesia", Jurnal Ekonomi dan Bisnis Indonesia, Vol 14, 4961.

Jusuf, S (1997), "Perkembangan dan Pengembangan Pariwisata Nasional serta Kecenderungan Pariwisata Internasional”, Kelola, Vol. 16, 4-10

Lundberg, D.E., Stavenga, M.H., dan Krishnamoorthy, M (1997), Ekonomi Pariwisata, PT. Gramedia Pustaka Utama, Jakarta.

Mill, R. C (1985), The Tourism System: an Introductory Tect, Prentice-Hall, New Jersey.

Parikesit, D dan Trisnadi, E (1997), "Kebijakan Kepariwisataan Indonesia dalam Pembangunan Jangka Panjang", Kelola, Vol 16, 11-20

Shuib, A dan Noor, N.A.M (1989), “Analisis Permintaan Pelancongan di Malaysia”, Pertanika, Vol $12(3), 425-432$.

Singh, D dan Siregar, R. Y (1997), ASEAN and Korea: Trends in Economic and Labour Relations, ISEAS, Singapore.

Spillane, J (1987), Ekonomi Pariwisata: Sejarah dan Prospeknya, Kanisius, Yogyakarta.

Vanegas, M dan Croes, R.R (2000), "Evaluation of Demand: US Tourists to Aruba", Annals of Tourism Research, Vol 27, No.4, 946-963

Witt, S.F dan Witt, C.A (1992), Modeling and Forecasting Demand in Tourism, Academic Press, London. 